Herpetologica, 61(1), 2005, 20-28

(c) 2005 by The Herpetologists' League, Ine.

\title{
SPATIAL AND TEMPORAL ECOLOGY OF EASTERN SPADEFOOT TOADS ON A FLORIDA LANDSCAPE
}

\author{
Cathryn H. Greenberg ${ }^{1,3}$ and George W. Tanner ${ }^{2}$ \\ 'USDA Forest Service, Southern Research Station, Bent Creek Experimental Forest, \\ 1577 Brevard Rd., Asheville, NC 28806, USA \\ ${ }^{2}$ George W. Tanner, Professor. Department of Wildlife Ecology and Conservation. \\ Institute of Food and Agricultural Sciences, Newins Zeigler 303, Box 110430, \\ University of Florida, Gainesville, FL 32611-0430, USA
}

\begin{abstract}
Effective amphibian conservation must consider population and landscape processes, but information at multiple scales is rare. We explore spatial and temporal patterns of breeding and recruitment by eastem spadefoot toads (Scaphiopus holbrookii), using nine years of data from continuous monitoring with drift fences and pitfall traps at eight ephemeral ponds in longleaf pine-wiregrass sandhills. Breeding events ( $>25$ adults at a pond within a month) occurred 23 times on nine occasions at seven of the eight study ponds, but substantial recruitment ( $\geq 100$ metamorphs) followed only five events. Recruitment ranged from $0-4648$ among ponds. Only four ponds functioned as population "sources", and only during some years. The other ponds, and even "source" ponds during some years, functioned either as "sinks," where breeding occurred with no resulting recruitment, or were not used at all for breeding. Most recruitment occurred during four years. Recruitment was correlated with adult breeding effort, but only during some years. Recaptures were rare, and inter-pond exchange of adults was minimal and short-distance $(<130 \mathrm{~m}$; one was $416 \mathrm{~m})$. Most $(83.5 \%$ ) individuals captured were metamorphs, and $15.9 \%$ were $>51 \mathrm{~mm}$ (est. $>4 \mathrm{yr}$ ). We conservatively estimated a 7-yr lifespan. Adult "population" trends clearly reflected breeding effort rather than numbers per se; capture rates fluctuated dramatically among years, but showed no overall trends during the 9 -yr study. Our paper is provides empirical information that can be used to generate realistic metapopulation models for $S$. holbrookii as a tool in conservation planning,
\end{abstract}

Key words: Amphibian populations; Anuran breeding; Ephemeral ponds; Hydroperiod; Metapopulation Scaphiopus holbrookii; Spadefoot toads; Temporary wetlands; Wetlands

AT FIRST glance, pond-breeding amphibians represent ideal metapopulation models using a "ponds as patches" paradigm, where populations continually become extinct and are recolonized by amphibians from neighboring ponds (Marsh and Trenham, 2001). However, this paradigm may not be realistic, either because metapopulation dynamics of a given species are not as they appear, or because assumptions are not met. Assumptions include: (1) extinctions and recolonizations commonly occur, (2) local extinctions are the result of stochastic processes in otherwise suitable breeding habitat, and (3) inter-pond distances influence recolonization processes due to limited dispersal ability by amphibians (Marsh and Trenham, 2001). In addition, perceived extinctions may be biased by sampling problems, such as species that are missed in surveys, skipped breeding seasons when climate or pond conditions are unsuit-

\footnotetext{
${ }^{3}$ Correspondence: e-mail, kgreenberg@fs.fed.us
}

able, or explosive breeding followed by long periods without breeding (Marsh and Trenham, 2001).

Accurate perceptions of amphibian metapopulation dynamics and population trends require long-term, landscape-scale studies to distinguish between local extinction and recolonization, natural population fluctuations, and true declines at a regional level (Blaustein et al., 1994; Gibbons et al., 1997; Pechmann et al., 1991). Long-term sampling at a single site provides vital information about amphibian pond use and life history, but sacrifices a landscape-scale perspective of community and metapopulation dynamics (Dodd, 1992; Semlitsch et al., 1996). Conversely, repeated "snapshot" sampling across multiple sites provides a broader spatial perspective, but sacrifices information about community and population dynamics (Cody, 1996; Semlitsch et al., 1995) and may miss information regarding distribution or site use (Skelly et al., 1999, 2003). Only intensive, concurrent, and continuous sampling of multiple sites over an 

extended period of time can capture the temporal and spatial variability of breeding, recruitment, longevity, and inter-pond movement that creates metapopulations.

Eastern spadefoot toads (Scaphiopus holbrookii) breed exclusively in fish-free, isolated, ephemeral ponds, and inhabit the surrounding uplands for most of their adult lives (Moler and Franz, 1987). Breeding is highly dependant on weather patterns and resulting pond hydrology; adults select ponds that have dried and recently refilled, likely to avoid high densities of invertebrate predators (Moler and Franz, 1987). Explosive breeding in this species occurs after heavy rains (Gosner and Black, 1955; Wright, 2002; Greenberg and Tanner, 2004). However, not all seemingly suitable ponds are selected for breeding, and not all heavy rains elicit explosive breeding by $S$. holbrookii (Greenberg and Tanner, 2004). Therefore, population persistence likely depends upon an interplay between weather, chance, and the suitability of both breeding ponds and the surrounding uplands (Delis et al., 1996). Much of what is known about $S$. holbrookii is derived from observation (Neill, 1957), short-term studies at one or a few sites (Bragg, 1961; Pearson, 1955), studies in upland habitat (Pearson, 1955), or experiments in artificial pools (Alford, 1989; Petranka and Kennedy, 1999; Wilbur et al., 1983; Wilbur, 1987). Little is known about the spatial and temporal dynamics of breeding ecology, or whether a metapopulation model fits the population ecology of $S$. holbrookit at the landscape level.

In this paper we use data from nine years (February 1994-January 2003) of continuous monitoring at eight, isolated, ephemeral ponds in Florida longleaf pine-wiregrass uplands to explore spatial and temporal pattems of breeding and recruitment by $S$. holbrookii. We examine life-history and behavioral attributes that could influence metapopulation dynamies. Specifically, we ask: (1) is breeding or juvenile recruitment spatially or temporally autocorrelated? (4) does breeding effort by adults affect recruitment levels, or is successful recruitment commonly subject to stochastic processes? (2) are extinctions and recolonizations common? (3) how might spatial and temporal patterns of breeding affect perceptions of population "blinking" and landscape- level population trends? Our paper is intended to provide empirical information that can be used to generate realistic metapopulation models for $S$. holbrookit as a tool in conservation planming.

\section{METHODS \\ Study Area}

This study was conducted at eight small (0.1-0.37 ha) isolated, ephemeral sinkhole ponds in longleaf pine-wiregrass sandhills on the Ocala National Forest in Marion and Putnam Counties, Florida. Ponds 1-4 were in fire-suppressed, hardwood-and sand pineinvaded sandhills. Despite attempts at habitat restoration (hardwood reduction) by burning at 1-4 year intervals during the past two decades, hardwood density and wiregrass cover remained patchy around Ponds 1-4. Ponds 5-8 were in savanna-like sandhills with a continuous wiregrass ground cover, widely spaced longleaf pine trees, and few hardwoods. Since 1976 the upland matrix surrounding these ponds has been regularly, successfully burned at 2-3 yr intervals (see Greenberg, 2001 for specific habitat characteristics; also see Greenberg and Tanner, 2004). Ponds $1-3$ are within $10-30 \mathrm{~m}$ of the regularly burned sandhills on one side, separated by a sand road. Ponds 7 and 8 are approximately $9.5 \mathrm{~km}$ south of the others.

\section{Drift Fence Sampling}

We installed drift fences $7.6 \mathrm{~m}$ long and spaced $7.6 \mathrm{~m}$ apart around $50 \%$ of each pond, and placed pitfall traps (19-liter buckets) on the inside and outside of both ends of each fence (four per fence) to detect directional movement by amphibians to and from ponds. We placed a sponge in each pitfall trap. Sponges were moistened as needed during trap checks to reduce the likelihood of desiccation. We positioned a double- or single-ended fimnel trap at the midpoint of each fence on both sides (two per fence).

Traps were routinely checked three times weekly from February 1994 through January 2003. Our resident volunteer alerted us when explosive breeding events occurred, and traps were checked the next day. When capture rates were low, we measured all first-captured 


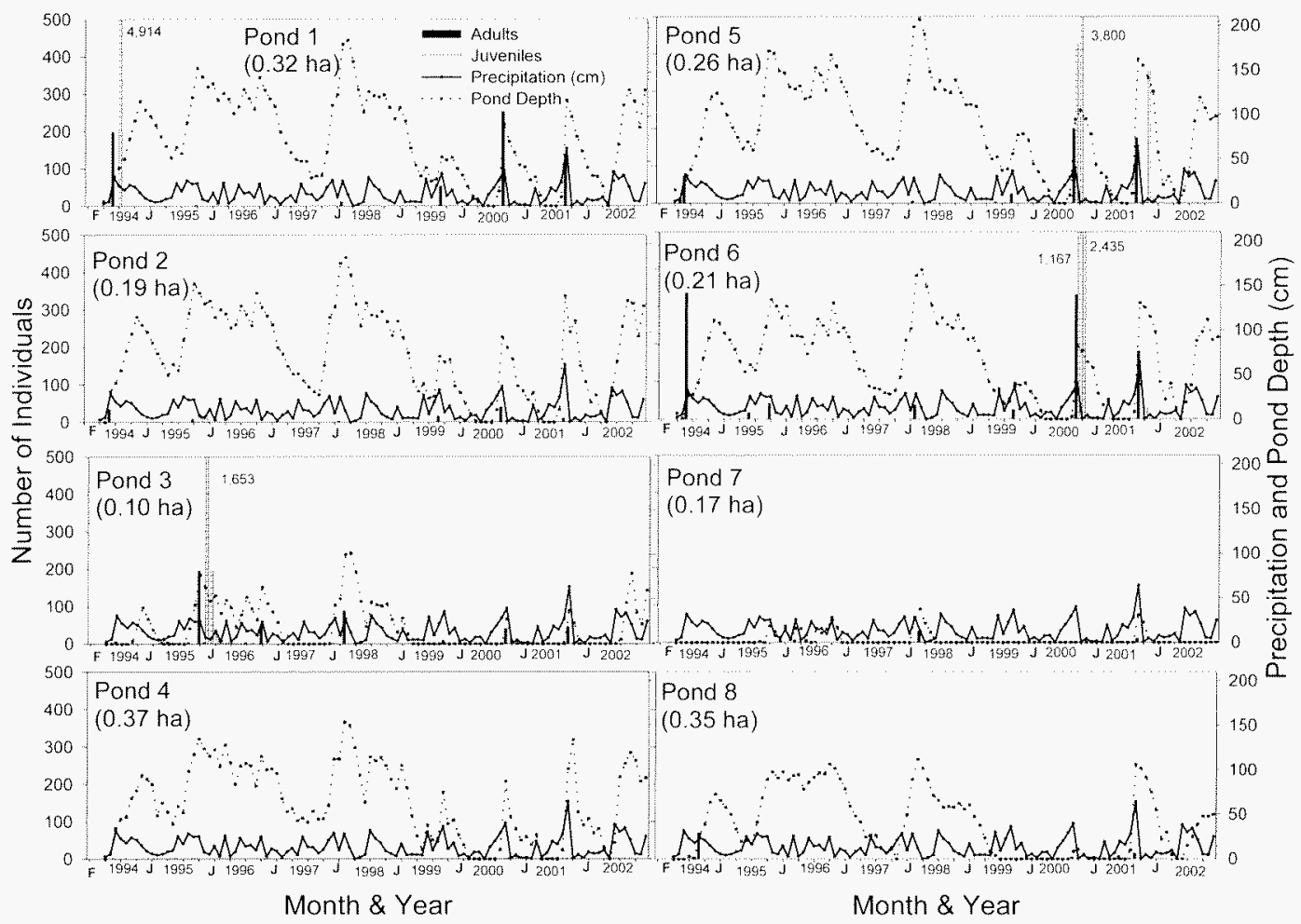

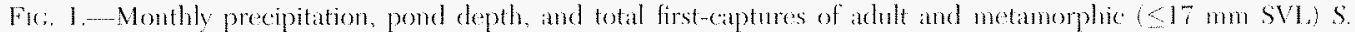
hollorokii during February (F on x-axis) 1994 - Jannary (J on x-ixis) 2003 at eight isolated, ephemeral ponds withn longleal pine-wiregrass sandhills. Ocala National Foresi, Marion and Putnam Comnties, Florida.

individuals and weighed them to the nearest 0.1 g using a hand-held Pesolat spring scale, sexed them (except metamorphs), and marked each according to pond number and year of capture by toe clipping. Recaptured animals were (rarely) re-clipped for original pond and year if needed. During breeding events only a subsample (ca. 30) per pond) of adults were measured and weighed, but all were sexed and toe-clipped. Similarly, newly metamorphosed toads were counted, but only a subsample was measured when they emigrated en masse; most were too small (ca. $\leq 11 \mathrm{~mm}$ ) to toe-clip. Recaptured toads were not measured. Animals were released on the opposite side of the fence at the point of capture.

We measured water depths weekly beginning in March 1994, and recorded temperature and rainfall daily at $0700 \mathrm{~h}$ beginning in April 1994. We used a Clobal Positioning System (CPS) to estimate distances among ponds.

\section{Statistical Analyses}

We used Wright's $(2002)$ cohort classifications to classify individuals, using SVL categories, as < l-yr old "metamorphs" $(8.5-17 \mathrm{~mm}$ ), or "adults", 1-(18-25 mm), 2-(26-37 mm), 3$(38-50 \mathrm{~mm}) 4-(51-61 \mathrm{~mm}), 5-(62-72 \mathrm{~mm})$, or 6-(73-8.3 $\mathrm{mm})$ yr old. For statistical analyses we considered all individuals $\geq 18 \mathrm{~mm}$ as adults (but adults $<51 \mathrm{~mm}$ were rarely captured, suggesting that they were nombreeding subadults). Recruits were conservatively defined as the number of metamorphs exiting ponds. We defined a breeding "event" as $n \geq 25$ adults at any single pond during a onemonth period, and a breeding "period" as the date of breeding at one or multiple ponds. In all statistical analyses we used only firstcaptured animals to eliminate potential confiusion cansed by inclusion of multiple captures of the same individuals.

Because S. holl rookii larvae develop rapidly, most breeding events and subsequent recruit- 


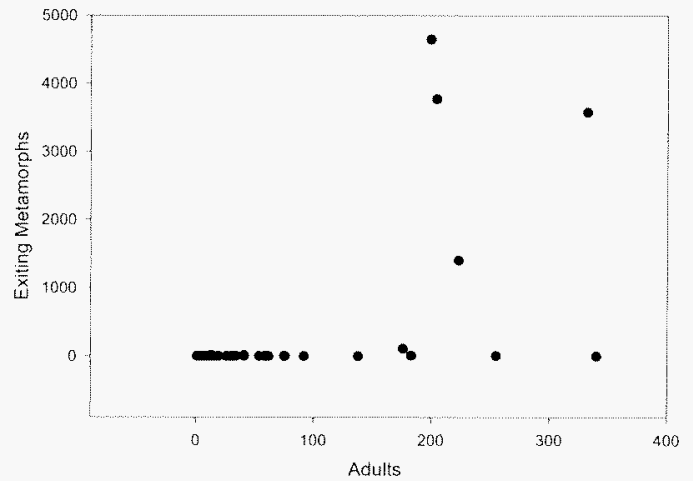

FIC. 2.--nelationship between the total (entering and exiting) number of first-captured $S$. hollorokit adults and number of recruits exiting metamorphs) from eight isolated, ephemeral ponds during nime years, Ocala National Forest, Marion and Putnam Comnties, Florida.

ment occurred during the same calendar year. As a result of a 13 October 1995 breeding, metamorphs exited Pond 3 from 6 November 1995 through May 1996 (but most by February 1996). All metamorphs from this breeding event were included with the 1995 data for correlation analysis.

We used Pearson product-moment correlations to examine the relationship between breeding effort by adults ( $\geq 18 \mathrm{~mm}$ SVL) and the number of recruits ( $\leq 17 \mathrm{~mm}$ SVL); all pond-years (one year at one pond) with at least one adult capture were included in the analysis. Visual inspection of the data suggested that we use an exponential model in this analysis.

We examined population trends over the 9-yr study period using Pearson's productmoment correlations. Population data for adults were square-root transformed for this analysis. We used paired t-tests to compare the arcsine square-root transformed proportion of total (immigrating + emigrating) males to females per pond during breeding events. We considered $P<0.05$ as statistically significant in our analyses.

\section{Results}

\section{Breeding and Recruitment}

A total of 23 breeding events by S. holbrookii occurred during nine periods

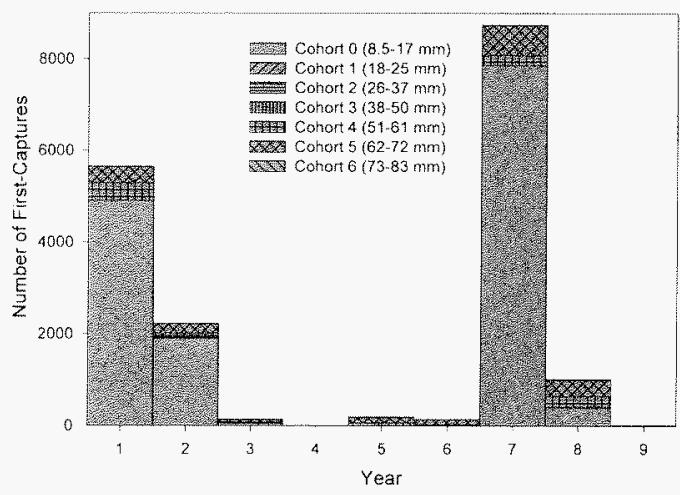

Fic: 3.-Annual size-distribution (\%) and population trends of $S$. holbrookii captured anmually February $1994-$ January 2003 at eight isolated, ephemeral ponds, Ocala National Forest, Marion and Putnam Counties, Florida. Size classes correspond with approximate age (years) (Wright, 2002)

(dates) at seven of the eight study ponds (Fig. 1). Most (six of nine) breeding periods occurred during September or October, but breeding also occurred during February, March, and Jume. Breeding was explosive, with up to 340 adults captured at any given pond within a $1-2$ day breeding period, but rarely otherwise (Fig. 1). Breeding occurred at only $1-5$ ponds per period, and only during seven of the nine years reported. Breeding events with $>175$ adults captured occurred in only $1-2$ ponds per period, and only during four of the study years. Four of the eight study ponds (Ponds 1, 3, 5, and 6) were used most frequently for breeding, and they produced most $(99.8 \%)$ of the recruits (Fig. 1).

Most metamorphs ( $89.5 \%$ ) were captured emigrating from ponds. Recruitment ranged from 0-4648 among ponds in any given year, and 0-7370 (ponds combined) among years. Most recruitment occurred during 1994, 1995 , 2000 , and 2001; and then only one or two of the four "productive" ponds (Ponds 1, 3, 5, and 6) produced most of the recruits. The remaining ponds were never used (Pond 4), used once (Ponds 7 and 8), or twice (Pond 2) for breeding, but none resulted in recruitment (Fig. 1). Substantial recruitment $(\geq 100$ metamorphs exiting ponds) occurred only five times during the 9 -yr period, or after only $22 \%$ of breeding events. 
TABLE 1. Total number of same-year and prior-years adult $S$. holbrooki recaptured annually at ejght isolated ephemeral ponds, Ocala National Forest, Marion and Putnam connties, Florida.

\begin{tabular}{|c|c|c|c|c|c|c|c|c|c|c|c|c|}
\hline \multirow[b]{2}{*}{ Recap year } & \multicolumn{9}{|c|}{ Year of first captome } & \multirow{2}{*}{$\begin{array}{l}\text { Total } \\
\text { f st cap }\end{array}$} & \multirow{2}{*}{$\begin{array}{l}\text { Total } \\
\text { rectap }\end{array}$} & \multirow{2}{*}{$\begin{array}{l}\text { Percent } \\
\text { recap }\end{array}$} \\
\hline & 1 & 2 & 3 & 4 & 5 & 6 & 7 & $s$ & 9 & & & \\
\hline 1 & 109 & 0 & 0 & 0 & 0 & 0 & () & 0 & 0 & 738 & 109 & 14.8 \\
\hline 2 & 38 & 16 & 0 & 0 & 0 & 0 & 0 & 0 & 0 & 322 & 54 & 16.8 \\
\hline 3 & 4 & 10 & 3 & 0 & 0 & 0 & 0 & 0 & 0 & 79 & 17 & 21.5 \\
\hline 4 & 0 & 0 & 0 & 0 & 0 & 0 & 0 & 0 & 0 & 5 & () & 0 \\
\hline 5 & $\mathrm{I}$ & 10 & 4 & 1 & 12 & 0 & 0 & 0 & 0 & 189 & 28 & 14.8 \\
\hline 6 & 1 & 0 & 0 & 1 & 1 & 18 & () & 0 & 0 & 143 & 21 & 14.7 \\
\hline 7 & 0 & 0 & 2 & 0 & 1 & 19 & 65 & 0 & 0 & 884 & 87 & 9.8 \\
\hline 8 & 0 & 0 & 0 & 0 & 0 & 0 & 3 & $6]$ & 0 & 618 & 64 & 10.4 \\
\hline 9 & 0 & 0 & 0 & 0 & 0 & 0 & 0 & 0 & 0 & 8 & 0 & 0 \\
\hline Total & 1.53 & 36 & 9 & 2 & 14 & 37 & 68 & 61 & 0 & 2986 & 380 & 12.7 \\
\hline
\end{tabular}

No substantial recruitment $(>100$ metamorphs) occurred following any breeding event (at a given pond) where $<175$ adults were captured, but did following five of the eight breeding events where $>175$ adults were captured (Figs. 1, 2). A few (1-16) metamorphs exited ponds following 11 other breeding events. We found a significant, exponential relationship between adult breeding effort and recruitment of metamorphs $\left(r^{2}=\right.$ $0.3364 ;$ RMSE $=755.36 ; F_{1,55}=27.88 ; P<$ 0.0001 ), indicating a threshold for the number of breeding adults, below which recruitment was negligible (Fig. 2). When examining the years separately, however, we found a significant relationship between adult breeding effort and recruitment during $1995\left(r^{2}=\right.$ $0.9325 ; R M S E=135.31 ; F_{1,6}=82.84 ; P<$ $0.0001), 1996\left(r^{2}=0.9646 ; R M S E=3.79\right.$; $\left.F_{1,3}=81.81 ; \mathrm{P}<0.005\right)$, and $2000\left(r^{2}=\right.$
$0.5285 ; R M S E=1261.14 ; F_{16}=6.73 ; P=$ 0.04 ), but not during other years.

\section{Population Structure and Trends}

A total of 2986 individual adult $S$. holbrookii and 15,145 metamorphs was captured; most $(97.6 \%)$ were captured in pitfall traps. Studyrelated mortality was $5.3 \%$, and was heaviest for adults due to suffocation by other $S$. holbrookii piled in pitfall traps. We captured significantly more males $(57.6 \%)$ than females $(42.4 \%)$ during breeding events $(t=-3.52$; $\mathrm{d}$ f $=22 ; P<0.005)$.

Most $(83.5 \%)$ captured S. holbrookii were metamorphs. Most adults were either in the 4 yr old $(34.7 \%)$ or 5 yr old $(62.1 \%)$ age classes (Fig. 3). Very few individuals in the smallest age classes ( $1-3$ yr: $2.3 \%$ ) were found; most of these were captured during nonbreeding periods. Individuals in the oldest cohort 6 yr:

TABLE 2. - Total number of same-pond and other-pond adult S. holbrookii recaptured during February 1994-January 2003 at eight isolated ephemeral ponds, Ocala National Forest, Marion and Putnam counties, Florida.

\begin{tabular}{|c|c|c|c|c|c|c|c|c|c|c|c|}
\hline \multirow[b]{2}{*}{ Recup pond } & \multicolumn{8}{|c|}{ Pond of origin } & \multirow{2}{*}{$\begin{array}{c}\text { Tot:al } \\
\text { lst (ai) }\end{array}$} & \multirow{2}{*}{$\begin{array}{l}\text { Total } \\
\text { recips }\end{array}$} & \multirow{2}{*}{$\begin{array}{l}\text { Recat\} } \\
\text { (क) }\end{array}$} \\
\hline & 1 & 2 & 3 & 4 & 5 & is & 7 & 8 & & & \\
\hline I. & 64 & 4 & 2 & 0 & 0 & 0 & 0) & 0 & 664 & 70 & 10.5 \\
\hline 2 & 3 & 8 & 1 & 0 & 0 & 0 & 0 & 0 & 123 & 12 & 9.8 \\
\hline 3 & 2 & 6 & 89 & 0 & 0 & 0 & 0 & 0 & 497 & 99 & 19.9 \\
\hline 4 & 0 & 0 & 0 & 1 & 0 & 0 & 0 & 0 & 15 & 1 & 6.7 \\
\hline 5 & 0 & 0 & 0 & 0 & 49 & 0 & 0 & 0 & 505 & 49 & 9.7 \\
\hline 6 & 0 & 0 & 0 & 0 & 0 & 1.32 & 0 & () & 990 & 132 & 1.3 .3 \\
\hline 7 & 0 & 0 & 0 & 0 & 0 & 0) & 2 & 0 & 71 & 2 & 2.8 \\
\hline 8 & 0 & 0 & 0 & 0 & 0 & 0 & 1 & 16 & 121 & 17 & 14.0 \\
\hline Total & 69 & 18 & 92 & 1 & 49 & 132 & 3 & 16 & 2986 & 380 & 12.7 \\
\hline
\end{tabular}


$0.9 \%$ ) also were rare; the largest individuals captured were $80 \mathrm{~mm}$ SVL (Fig. 3).

We found no consistent relationship between study year and number of adults ( $\geq 18$ $\mathrm{mm})\left(F_{1.7}=0.11 ; P=0.7493\right)$, indicating that, overall, the population did not increase or decrease during the 9-year study period (Fig. 3).

\section{Multi-year Recaptures and Inter-pond Movement}

A total of $12.7 \%$ of first-captured adults were recaptured (380 of 2986). Most recaptures occurred during the same year as their original capture (Table 1). However, several individuals were captured $\geq 2$ yr after, indicating that they were at least three years old (because most metamorphs were too small to toe-clip); two individuals were recaptured after five years, and one was recaptured after six years, indicating that $S$. holbrookii can live at least seven years (Table 1 ).

Most $(95 \%)$ adult recaptures occurred at the pond where they were first captured (Table 2). Minimal exchange of adults occurred among Ponds 1,2 , and 3 (maximum distance $130 \mathrm{~m}$ ), and one individual was recaptured at Pond 8 , approximately $416 \mathrm{~m}$ from Pond 7 where it was originally marked (Table 2). Because most metamorphs were not marked we could not determine whether they used nonnatal ponds for breeding as adults.

\section{Discussion}

Our data provide empirical information that can be used in developing realistic metapopulation models for S. holbrookii. We found that all ponds were not "created equal" either as breeding sites or as sources of juvenile recruitment. S. holbrookii bred in variable numbers among some, but not all seemingly suitable ponds. Among the eight ponds we studied, only half (Ponds $1,3,5$, and 6) were used frequently, though irregularly, for breeding. Only this subset of ponds functioned as population "sources" (Pulliam, 1988), producing most (99.8\%) metamorphs during the 9 -year study period. Yet, even the four "source" ponds were sources of recruitment during only one (Ponds 1,3 , and 6) or two (Pond 5) of the nine years studied; they functioned as "sinks" (where breeding resulted in no recruitment) or were not used at all for breeding during the other years. The other ponds functioned either as "sinks," where breeding occurred rarely and in low numbers, but resulted in no recruitment (Ponds 2, 7, and 8), or were never used for breeding (Pond 4). Among-pond differences in breeding and recruitment did not appear related to hydrology, which was similar among most ponds (Greenberg and Tanner, 2004).

Conceptually, a "metapopulation" incorporates at least some dispersal among distinct populations (in this case, ponds) (Hanski and Simberloff, 1997). We found minimal "rescue" (Pulliam, 1988), or dispersal by adults among ponds, and short distances (except once) when it occurred. Yet, the interval between breeding events at a given pond exceeded the apparent lifespan of most individuals (we estimated a maximum lifespan of $7 \mathrm{yr}$ ); too long to sustain a viable population if ponds did not receive immigrants from surrounding ponds. For example, large numbers of adults bred at Ponds 5 and 6 in 2000 , although the last substantial recruitment occurred sometime before the study began in 1994 (at least 7.5 yr earlier). This incongruity between apparent pond fidelity versus within-pond recruitment intervals that should lead to local extinction, could be because (1) adult $S$. holbrookii are philopatric but live longer than we estimated, (2) adults move among ponds more than we detected, or (3) metamorphs disperse and breed in nonnatal ponds as adults.

Because we did not mark emigrating metamorphs we could not assess their dispersal. Most metamorphs entering ponds were captured during mass exodus events from those ponds, suggesting that they were part of the same recruitment event. However, our data did suggest that some short-distance interpond movement occurred (Greenberg and Tamner, 2004). Genetic analyses would shed more light on the metapopulation connectivity among ponds.

Although breeding events were highly synchronized among subsets of ponds during each breeding period, recruitment was not. Breeding effort was an important determinant of recruitment during some, but not all years. Substantial recruitment never occurred when $<175$ adults were captured during a breeding event at any given pond, suggesting that there may be a critical threshold of breeding effort, 
eggs, or tadpoles for substantial survival to metamorphosis to occur. Dodd (1992) reported only one large S. holbrookii breeding event in five years at a pond in north-central Florida, but no recruitment. Semlitsch et al. (1996) also reported one successful recruitment of S. holbrookii despite repeated breeding events over 16 years in a Carolina Bay in South Carolina.

Recruitment was essentially an "all or none" occurrence. Substantial recruitment occurred following only five of 23 breeding events, and was not spatially or temporally synchronized across the study ponds. Recruitment occurred at only one of eight ponds during three years (1994, 1995, and 2001), and at two ponds during 2000 . Other studies have shown that survival of anuran larvae to metamorphosis is affected by numerous factors including water temperature (Gosner and Black, 1955), premature pond-drying, intra- and interspecific competition, predation on eggs or larvae by vertebrate and invertebrate predators, and a complex interplay of predator phenology and prey assemblages (Alford, 1989; Petranka and Kennedy, 1999; Wilbur, 1983, 1987). We suggest that predation on eggs and larvae had a major effect on recruitment success because (1) breeding events were strongly associated with ponds that had recently dried and refilled-one way to avoid high predator densities that may increase with longer hydroperiods, (2) each substantial recruitment occurred only in ponds that had recently dried and refilled prior to breeding events (Greenberg and Tanner, in press), and (3) there was an apparent "minimum threshold" of breeding adults-likely resulting in densities of eggs and larvae that were potentially high enough to "swamp" predators thereby allowing substantial recruitment to occur. Causes aside, $S$. holbrookii recruitment is clearly heavily subject to stochastic processes. This lack of spatial autocorrelation may have important implications for developing probabilistic models of patch occupancy by amphibians (Knapp et al., 2003; Trenham et al., 2003).

Despite dramatic differences in adult captures and recruitment among ponds and years, the adult population was relatively stable over the life of our study. Sampling over a shorter subset of years, however, might have led us to conclude that the population was declining, or even locally extinct. Our data show that, based on trapping at breeding ponds, perceptions of S. holbrookit abundance are heavily biased by weather, pond hydrology (Greenberg and Tanner, 2004), and breeding phenology. In our study, apparent reduced populations of adult $S$. holbrookii during some years clearly reflected suspended breeding activity rather than low densities. The probability that only a portion of the potential adult breeding pool actually breeds during any given breeding event further biases population estimates (Gosner and Black, 1955). In our study, individuals $18-50 \mathrm{~mm}$ SVL were rarely captured at ponds; most captured individuals were 51-72 $\mathrm{mm}$ SVL, or about 4-5 yr old (Wright, 2002). This indicates that large numbers of juvenile and subadult $S$. holbrookii remain in uplands surrounding ponds for 34 years before appearing at ponds for their first breeding at age 4 or 5 . Population "reservoirs" that are not detected at breeding ponds thwart accurate estimation of populations and population trends, and may give a misleading impression of among-pond extinctions and recolonizations that have important implications for metapopulation modeling.

Similarly, sampling any subset of our eight study ponds might have left us with a very different impression of $S$. holbrookii breeding and recruitment dynamies. This result illustrates the importance of long-term, landscapelevel studies to distinguish natural amphibian population fluctuations, or perceptions of population fluctuations, from true declines (Pechmann and Wilbur, 1994). Even the relatively larger spatial and temporal scope of our study is likely inadequate to capture the true timelandscape complexity of their population dynamics.

Effective amphibian conservation must be built upon metapopulation models that incorporate accurate, empirical knowledge of spatial and temporal population dynamics and species-specific life-history traits that affect persistence at a landscape level. Our study illustrates the potential contribution of each individual wetland, regardless of its proximity to others, as evidenced by wide differences in breeding events and recruitment among ponds, among years within ponds, and by the apparent rarity of long-distance movement or inter-pond "rescues" by adult $S$, holbrookit. 
Although we could not track inter-pond movement by metamorphs, it appears likely that they "rescue" local populations by breeding - 4 or 5 years later-in nomnatal ponds as adults. Our inability to substantiate that S. holbrookii finction as metapopulations further emplasizes the importance of conserving multiple wetlands. Closely dustered wetlands would likely increase the likelihood of recruitment success within a landscape neighborhood during at least some years and ponds, and enhance the probability of interpond movement. Clusters of ponds that are spaced at varying distances from one another may increase the likelihood of population persistence at a larger scale.

Ackoneledgments - Funding was prowided by the USDA Forest Service, includeng the Ocala vational Forest, the Longleaf Pine Ecosystem Restoration Program, and the Sonthern Research Station's Bent Creek Experimental Forest; the Department of Energy-Savannah River Operations office througl the Foresf Service Savaniah River Site and the Forest Service Sotthern Research Station under Interagency Agreement DE-Alo9765800056 , and the Florida Fish and Wildlife Conservation Commission, Burean of Wildlife Diversity Conservattion, contrats NG99-014 and Cl195. We thank J. Beach for field and logistical assistance, and for her dedication to this study, C. MC.Mahon. D. Loltis, and J. Blake provided critical support to the study. R. Ashton. M. Welker. I. Smith, J Staiger, J. Barichivich, R. Owen, D. Johmson, SS. Johnson, J. Wiebe K. Garen, and others have provided excellent field assistance and/or onsite project management. D. Johnson created the studly site map. We also thank Ocalat National Forest staff officers, including L. Lowery, R. Lowery, C. Sekerak, I. Cluts, and M. Clere, and the Ocalat fire crew. I. Petranka, S. folnoson, and K. Kinkead gave valuable sugerestions lor inproving an earlier version of this mamuscript.

\section{LUTHRATURE (ATED)}

Alsons, R, A, 1989. Variation in predator plemology alfects predator performance in prey community composition. Ecology 70:206-219

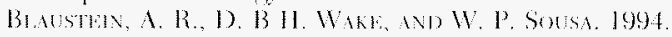
Amphibian declines: judging stability, persistence, and susceptibility of populitions to local and ghobal extinctions. Comservation Biology s:60) 71 .

Brasa, A. N. 1961. The hehavior and comparative developmental rates in mature of tadpoles of a spadefoot, a loid, and a froes. Herpetologica 17:80 -94.

(o) $)$ M. L. 1996 . Introduction to longeterm commonity ecological studies. I'p. 1-15. In M. L. Cooly and J. A. Smallwood (Fids.) Lomg-tem Studies of Vertebrate

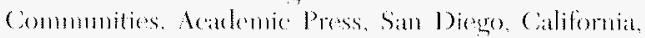
U.S.A.

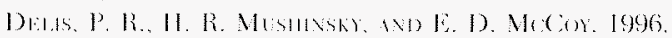

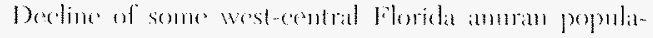

toons in response to habitat degradation. Biodiversity and Conservation 5:1579-1595.

Donb, C. K. JR. 1992. Biological diversity of a temporary pond herpetofama in north Florida sindhills. Biodiversity and Conservation 1:125-142.

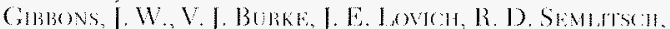

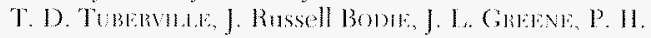

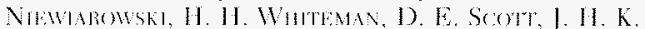
Plaman, (C. R. Harlison, S. H. Bronet, J. D.

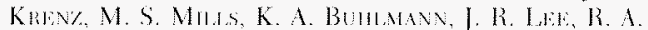
Smol: A. 1). Théklis, T. M. Muls T. Lamb, M. E. Domas, J. D. Covobon, M. II Swlut, D. II. Nason, M. B. DHeTsen, H. G. Hanin, J. A. OT, AND D. J. Kanaptakis. 1997. Perceptions of species abindance. distribution, and diversity: lessons from four decades of sampling on at government-managed reserve. Fnvirommental Management 21:259-26s.

Gowme K. L. AND 1. H. Brack. 1955. The effects of temperature and moisture on the reproductive cycte of Sraphiopus h. holbooki. American Midland Naturalist $54: 192-203$

Gaknakro, C. 11, 2001. Spatio-temporal dynamies of pond use and recruitment in Floridat gopher frogs (Rema capito aesopus). Jommal of Herpetology 35:74-\$5.

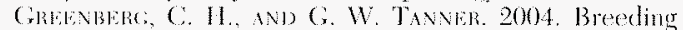
pond selection and movement pattens by spadefoot toads (Scaphiopus holbrookii) in relation to weather and edaphic conditions. Joumal of Herpetology 38:569-577.

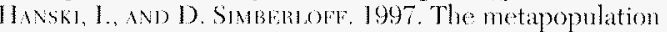
approach, its history, conceptral domain, and application to conservation. Pp. 5-26. In I. A. Hanski and M. E. Gilpin (Eds), Metapopulation Biology. Academic Press. San Diego, California, U.S.A.

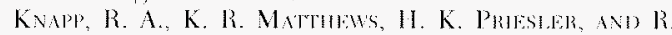
JE1.ASoN. 20033. Developing probabilistic models to predict amphibian site occupancy in a patchy landscape. Ecologicat Applications 1.3:1069-1052

Marsil, D. M. AND P. C. Tlisinum 2001. Metapopulation dynanies and amphibian conservation. Conservation Biology 15:40 49.

Momik, P. E., ANo R. Fravz. 19S7. Widdlife values of small, isolated wetlands in the sontheastem coastal plain. PP. 2:34.241. In R. R. Odum, K. A. Riddleberer, and I. C. Ozier (Eds.). Procedings of the $3^{\text {rd }}$ S.F. Nongame and Endangered Wildlife Symposinm. Georgia Department of Natural Resomeces, Atlanta, Georgia, U.S.A.

Nitl, W. T. 1957. Notes on metamorphic and breeding ageregrations of the eastern spadefoot, Scaphiopus hollorooki (IIarlan). Herpetologica 13:155-187.

Pransen, P. C. 1955. Popmlation exology of the spadefoot

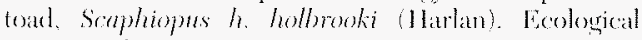
Monographs 25:23:-267.

Padiman, J. F. K., and 11. M. Whaker. 1994. Putting declining amphibian populations in perspective: natural fluctuations and human impacts. Herpetologica 50 ): 6.5 .54$.

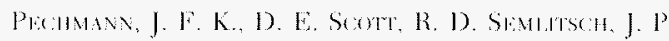

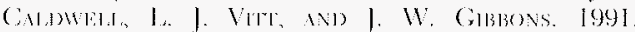
Declining amplibian populations: the problem of separating human impacts fom natural fluctmations. Science 253:592-895

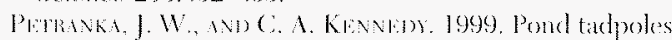
with gemeralized norphology: is it time to reconsides 
their functional roles in aquatic communities? Oecologia $120.621-631$.

Puthiam, H. R. 1988. Sources, sinks, and population regulation. American Naturalist 132:652-661.

Semirsom, R. D., J. W. Gmbons, and T. D. Tubenville. 1995. Timing of reproduction and metamorphosis in the Carolina gopher frog (Rana capito capito) in South Carolina. Jommal of Herpetology 29:612-614.

SEMLATSCH, R. D., D. E. SCOTT, ]. H. K. PECHMANN, AND J. W. GBbons. 1996. Structire and dynamics of an amphibian community: evidence from a 16 -year study of a natural pond. Pp. 217-248. In M. L. Cody and J. A Smallwood (Eds.), Long-term Studies of Vertebrate Communities. Acadenic Press, San Diego, California, U.S.A.

Skeliy, D. K., E, E. Whaner, and S. A. Cortwhicht 1999. Long-term distributional dynamies of a Michigan amphibian assemblare. Ecology 80:2326-2337.

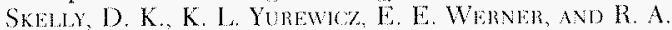
Rexpes, 2003. Estimating decline and distributional change in amphibians. Conservation Biology 17. $744-751$.

Trenham P. C. W. D. Kofvik; M. I. Mossman, S. 1. STAR, AND L. A. JAGOR. 2003. Regional dynamics of wetland-breeding frogs and toads: tumover and synchrony. Ecological Applications 13:1522 1532.

Wubcr, H. M. 1957. Regulation of structure in complex systems: experimental temporary pond communities. Ecology $68: 143 \%-1452$

WilbUR, H. M., P. I. MORIN, AND R. N. HARRIS. 1983. Salamander predation and the structure of experimental communities: anuran responses. Ecology 64:1423-1429.

Whatu, A. H. 2002. Life-histories of the Frogs of the Okefinoke Swamp, Georgia. North American Salientia (Anura) No. 2. Comell University Press, Ithaca, New York, U.S.A.

Acceted: 14 September 2004

Asocinte Editor: Michael Angilletta 